\title{
MENINGKATKAN PROFESIONALISME GURU AGAMA HINDU
}

\author{
Oleh \\ Ni Nyoman Sri Widiasih \\ Dosen pada Fakultas Brahma Widya IHDN Denpasar
}

\begin{abstract}
This paper aims to provide a correct understanding of the importance of quality and professionalism of Hindu religious teachers in education. A teacher of religion, especially Hindu religious teachers is not just a job assigned to transfer knowledge but also served to instill the values of the teachings of Hinduism to the learners. Hindu religious teachers are professional positions, hence a teacher demanded to carry out their duties professionally. The professionalism of a teacher can be seen from how to run any of the duties is always productive, innovative, efficient and effective and independent

To be a Hindu religious teacher who is able to carry out their duties in a professional manner, the necessary efforts both from its own consciousness and on the government's efforts. In an effort to become a Hindu religious teachers qualified and professional, then a Hindu religious teachers is not enough to just rely on what the government has programmed as with training, workshops, competition research, as well as awards in the form of allowance teacher certification, and seminars, but a Hindu religious teachers are required to understand the teachings of Hinduism as a whole and want to fill themselves with the knowledge and responsiveness to changing times and technological advances. Thus, the material being taught will always correspond with the times and the material can be innovative, efficient and effective in their delivery in the classroom.

Finally the success of a teacher of religion in their profession will appear on the character and attitude of the learners who become responsible, religious and good behavior.
\end{abstract}

Keywords: professional, teacher of religion, character

\section{PEDAHULUAN}

Alam semesta beserta isinya diyakini diciptakan oleh Tuhan. Dari awal penciptaan alam semesta beserta isinya selalu berubah seiring dengan perubahan ruang dan waktu. Oleh karena alam terus berubah, makanya manusia yang hidup di dalamnya akan selalu juga berubah mengikuti perubahan itu. Jika manusia tidak berubah, maka akan ditinggalkan oleh perubahan, sehingga tidak mampu hidup harmonis dengan alam. Demikian pula tugas yang diembang oleh seorang guru, yang harus senantiasa berubah seirama dengan perkembangan jaman dalam proses pembelajaran. Hal ini dapat dilakakukan dengan usaha yang maksimal untuk senantiasa 
beradaptasi dalam ilmu pengetahuan dan teknologi informasi. Terlebih lagi perkembangan ilmu pengetahuan dan teknologi informasi sangat cepat, sehingga diperlukan usaha yang sungguh-sunguh dalam merealisasikan secara kontekstual. Saat ini, semua guru-guru harus berpacu menyesuaikan pengetahuannya dengan perkembangan jaman yang semakin canggih, dan hampir semua administrasi keguruan akan semakin "paperless" sehingga semua akan serba online. Jika perkembangan IPTEKS ini tidak diimbangi dengan perkembangan kemampuan beradaptasi dalam ilmu pengetahuan dan teknologi informasi, maka guru-guru akan ketinggalan dalam proses pembelajaran.

Perkembangan ilmu pengetahuan dan teknologi akan memberikan pengaruh dan perubahan yang pesat pada peserta didik sehingga moral dan karakter siswa akan semakin sulit dibina jika pengaruh negatif dari IPTEKS lebih banyak berpengaruh pada dirinya. Hal ini merupakan tantangan yang berat bagi guru-guru khususnya guru agama, yang nota benanya lebih menekankan pada perubahan prilaku kea rah yang lebih baik sehingga menjadi anak didik yang berkarakter. Tantangan bagi guru di era global ini yang mengharuskan para guru harus berpacu dengan kemampuan yang kontekstual.

Seorang guru agama Hindu hendaknya menyadari bahwa tugas yang diembannya merupakan jabatan profesi yang keberadaannya tidak dapat tergantikan oleh orang lain walaupun berasal dari profesi yang sama. Oleh karena itu, guru memiliki tugas yang sangat mulia dalam mencerdaskan anak bangsa serta mampu melahirkan generasi bangsa yang beriman, bertakwa, dan berahlak mulia, serta menguasai ilmu pengetahuan dan seni keagamaan Hindu.

Dalam Undang-Undang RI Nomor 14 tahun 2005, pasal 1 ayat 1 disebutkan bahwa guru adalah pendidik profesional dengan tugas utama mendidik, mengajar, membimbing, mengarahkan, melatih, menilai dan mengevaluasi peserta didik pada pendidikan anak usia dini jalur pendidikan formal, pendidikan dasar, dan pendidikan menengah. Selanjutnya pada pasal 1 ayat 2 disebutkan profesional adalah pekerjaan atau kegiatan yang dilakukan oleh seseorang dan menjadi sumber penghasilan kehidupan yang memerlukan keahlian, kemahiran atau kecakapan yang memenuhi standar mutu atau norma tertentu serta memerlukan pendidikan profesi.

Untuk dapat menjadi guru professional tidaklah mudah perlu melakukan beberapa upaya seperti mampu menemukan jati diri sebagai tenaga pendidik dan mampu mengaktualisasikan diri secara nyata ke dalam setiap proses pembelajaran. Sementara fenomena yang terjadi adalah pemberian skala prioritas kepada guru sangat rendah, akibatnya pembangunan pendidikan akan berdampak buruk yang sangat luas bagi kehidupan berbangsa dan bernegara terutama dalam menghadapi daya saing di tingkat global. Oleh karena itu, dalam hal mengembangkan profesionalisme guru di Indonesia diperlukan pembinaan secara berkelanjutan yang tujuannya agar mutu pendidikan agama Hindu bisa sejajar dengan mutu pendidikan umum lainnya.

\section{PEMBAHASAN \\ 2.1. Pengertian Profesionalisme}

Secara estimologi, istilah profesi berasal dari bahasa Inggris yaitu profession atau bahasa latin, profecus, yang artinya mengakui, adanya pengakuan, menyatakan mampu, atau ahli dalam melakukan suatu pekerjaan. Sedangkan secara terminologi, profesi berarti suatu pekerjaan yang mempersyaratkan pendidikan tinggi bagi pelakunya yang ditekankan pada pekerjaan mental; yaitu adanya persyaratan pengetahuan teoritis sebagai instrumen untuk melakukan perbuatan praktis, bukan pekerjaan manual (Danin, 2002) dalam Rusman (2011:16). 
Dalam Kamus Besar Bahasa Indonesia edisi ketiga, istilah profesi, profesional, profesionalisme dan profesionalitas dapat dibedakan menjadi beberapa kelompok, diantaranya adalah sebagai berikut:

1. Profesi ialah bidang pekerjaan yang dilandasi pendidikan keahlian tertentu (keterampilan, kejuruan, dsb).

2. Profesional ialah: a) bersangkutan dengan profesi, b) memerlukan kepandaian khusus untuk menjalankannya, c) mengharuskan adanya pembayaran untuk melakukannnya.

3. Profesionalisme ialah mutu, kualitas, dan tindak tanduk yang merupakan ciri suatu profesi atau orang yang profesional.

4. Profesionalitas ialah a) perihal profesi, b) keprofesian, c) kemampuan untuk bertindak secara profesional. (Barnawi dan Arifin, 2012a:110)

Menurut Rusman(2011:16) Profesi adalah suatu pekerjaan yang dalam melaksanakan tugasnya memerlukan/menuntut keahlian (expertise), menggunakan teknik-teknik ilmiah, serta dedikasi yang tinggi. Keahlian diperoleh dari lembaga pendidikan yang khusus diperuntukkan untuk itu dengan kurikulum yang dapat dipertanggungjawabkan.

Jika disimpulkan pemakaian istilah profesi sesungguhnya menunjuk pada suatu pekerjaan atau jabatan yang menuntut keahlian, tanggungjawab, dan kesetiaan terhadap bidang tugas yang diembannya. Secara teoritis, suatu profesi tidak bisa dilakukan oleh sembarang orang yang sebelumnya tidak dilatih atau disiapkan untuk bidang profesi tersebut.

\subsection{Syarat-Syarat Guru Profesional}

Untuk menjadi guru professional diatur dalam undang-undang nomor 14 tahun 2005 tentang guru dan dosen yang kemudian oleh Moh.Ali (2008) dalam Uzer Usman (2011:15) menyatakan bahwa guru professional hendaknya memiliki persyaratan sebagai berikut:

1. Menekankan pada suatu keahlian dalam bidang tertentu sesuai dengan bidang profesinya.

2. Menuntut adanya tingkat pendidikan keguruan yang memadai.

3. Adanya kepekaaan terhadap dampak kemasyarakatan dari pekerjaan yang dilaksanakannya.

4. Memungkinkan perkembangan sejalan dengan dinamika kehidupan.

Sementara itu, Robert W. Richey (1974:11) dalam Buchari Alma (2010:117-118) mengemukakan ciri-ciri dan syarat-syarat profesi sebagai berikut:

1. Lebih mementingkan pelayanan kemanusian yang ideal daripada kepentingan pibadi,

2. Seorang pekerja sosial secara relatif memerlukan waktu yang panjang untuk mempelajari konsep serta prinsip-prinsip pengetahuan khusus yang mendukung keahliannya.

3. Memiliki kualifikasi tertentu untuk memasuki profesi tersebut serta mampu mengikuti perkembangan dalam pertumbuhan jabatan.

4. Memiliki kode etik yang mengatur keanggotaan, tingkah laku, sikap serta kerja.

5. Mebutuhkan suatu kegiatan intelektual yang tinggi

6. Adanya organisasi yang dapat meningkatkan standar pelayanan, disiplin dari dalam profesi serta kesejahteraan anggotanya.

7. Memberikan kesempatan untuk kemajuan, spesialisasi, dan kemandirian

8. Memandang suau profesi sebagai suatu karier hidup dan menjadi anggota permanen 
9. Mampu menjaga profesi ditengah kehidupan masyarakat yang terus mengalami perubahan.

\subsection{Karakteristik Guru Profesional}

Menurut Ornstein dan Levine (1984) dalam Rusman (2011:24) menyatakan bahwa profesi itu adalah jabatan yang sesuai dengan pengertian profesi di bawah ini:

1. Melayani masyarakat merupakan karier yang akan dilaksanakan sepanjang hayat.

2. Memerlukan bidang ilmu dan keterampilan tertentu diluar jangkauan khalayak ramai.

3. Menggunakan hasil penelitian dan aplikasi dari teori ke praktik.

4. Memerlukan pelatihan khusus dengan waktu yang panjang.

5. Terkendali berdasarkan lisensi buku dan atau mempunyai persyaratan yang masuk.

6. Otonomi dalam membuat keputusan tentang ruang lingkup kerja tertentu

7. Menerima tanggung jawab terhadap keputusan yang diambil dan unjuk kerja yang ditampilkan yang gerhubungan dengan layanan yang diberikan

8. Mempunyai komitmen terhadap jabatan dan klien.

9. Menggunakan administrator untuk memudahkan profesinya relatif bebas dari supervisi dalam jabatan

10. Mempunyai organisasi yang diatur oleh anggota profesi sendiri.

11. Mempunyai asosiasi profesi dan atau kelompok 'elit' untuk mengetahui dan mengakui keberhasilan anggotanya

12. Mempunyai kode etik untuk menjelaskan hal-hal yang meragukan atau menyangsikan yang berhubungan dengan layanan yang diberikan
13. Mempunyai kadar kepercayaan yang tinggi dari publik dan kepercayaan diri setiap anggotanya

14. Mempunyai status sosial dan ekonomi yang tinggi.

Bila disimpulkan pernyataan tersebut hampir sama dan saling melengkapinya. Dengan demikian ciri-ciri profesi yang dimaksud diantara adalah sebagai berikut :

1. Pilihan terhadap jabatan itu didasari oleh motivasi yang kuat dan merupakan panggilan hidup orang bersangkutan

2. Telah memiliki ilmu, pengetahuan, dan keterampilan khusus yang bersifat dinamis dan terus berkembang

3. Ilmu, pengetahuan, dan keterampilan khusus tersebut diatas diperoleh melalui studi dalam jangka waktu lama

4. Punya otonomi dalam bertindak ketika melayaniklien

5. Mengabdi kepada masyarakat atau berorientasi kepada layanan sosial, bukan untuk mendapatkan keuntungan finansial semata

6. Tidak mengdivertensikan keahliannya untuk mendapatkan klien

7. Menjadi anggota organisi profesi

8. Organisasi tersebut menentukan persyaratan penerimaan anggota, membina profesi anggota, mengawasi prilaku anggota, memberi sanksi, dan memperjuangkan kesejahteraan anggota.

9. Memiliki kode etik profesi

10. Punya kekuatan dan status yang tinggi sebagai ekspert yang diakui oleh masyarakat

11. Berhak mendapat imbalan yang layak

12. Berhak mendapat pengakuan secara sah dari masyarakat

13. Berhak mendapat perlindungan dalam melaksanakan tugas profesinya. 


\subsection{Langkah-langkah Pengembangan Profesionalisme Guru \\ Menurut Danim (2011:94) dalam} mengembangkan profesi guru dapat dilakukan melalui berbagai strategi dalm bentuk pendidikan dan pelatihan (diklat) maupun bukan diklat, antara lain;

\section{Pendidikan dan pelatihan}

\section{A. In-house training (IHT).}

Pelatihan dalam bentuk IHT adalah pelatihan yang dilaksanakan secara internal dikelompok kerja guru, sekolah, atau tempat lain yang ditetapkan untuk menyelenggarakan pelatihan. Strategi pembinaan melalui IHT dilakukan berdasarkan pemikiran bahwa sebagian kemampuan dalam meningkatkan kompetensi dan karier guru tidak harus dilakukan secara eksternal, tetapi dapat dilakukan oleh guru yang memiliki kompetensi yang belum dimiliki oleh guru lain. Dengan srategi ini diharapkan dapat menghemat waktu dan biaya.

\section{B. Program Magang.}

Program magang adalah pelatihan yang dilaksanakan didunia kerja atau industri yang relevan dalam rangka meningkatkan kompetensi profesional guru. Program magang ini diperuntukan bagi guru dan dapat dilakukan selama periode tertentu, misalnya, magang disekolah tertentu untuk belajara menejemen kelas atau menejemen sekolah efektif. Program magang dipilih sebagai alternatif pembinaan dengan alasan bahwa keterampilan tertentu yang memerlukan pengalaman nyata.

C. Kemitraan Sekolah.

Pelatihan melalui kemiraan sekolah dapat dilaksanakan antara sekolah yang baik dan kurang baik, antara sekolah negeri dan swasta. Jadi pelaksanaannya dapat dilakukan di sekolah atau di tempat mitra sekolah. Pembinaan lewat mitra sekolah diperlukan dengan alasan bahwa beberapa keunikan atau kelebihan yang dimiliki mitra, misalnya, dibidang menejemen sekolah atau kelas.

D. Belajar jarak jauh.

Pelatihan melalui belajar jarak jauh dapat dilaksanakan tanpa menghadirkan instruktur dan peserta pelatihan dalam satu tempat tertentu, melainkan dengan sistem pelatihan melalui internet dan sejenisnya. Pembinaan lewat belajar jarak jauh dilakukan dengan pertimbangan bahwa tidak semua guru terutama di daerah terpencil.

E. Pelatihan berjenjang dan khusus. Pelatihan jenis ini dilaksanakan di lembaga-lembaga pelatihan yang diberi wewenang, dimana program disusun secara berjenjang mulai dari jenjang dasar, menengah, lanjut, dan tinggi. Jenjang pelatihan disusun berdasarkan tingkat kesulitan dan jenis kompetensi. Pelatihan khusus (spesialisasi) disediakan berdasarkan kebutuhan khusus atau disebabkan adanya perkembangan baru dalam keilmuan tertentu.

F. Kursus singkat di perguruan tinggi atau lembaga pendidikan lainnya.

Kursus singkat dimaksud untuk melatih meningkatkan kemampuan guru dalam beberapa kemampuan melakukan penelitian tindakan kelas, menyusun karya ilmiah, merencanakan, melaksanakan, dan mengevaluasi pembelajaran.

G. Pembinaan internal oleh sekolah. Pembinaan internal ini dilaksanakan oleh kepala sekolah dan guru-guru yang memiliki kewenangan membina, melalui rapat dinas, rotasi tugas 
mengajar, pemberian tugas-tugas internal tambahan, dan diskusi dengan teman sejawat.

\section{H. Pendidikan lanjut.}

Pembinaan profesi guru melalui pendidikan lanjut juga merupakan alternatif bagi peningkatan kualifikasi dan kompetensi guru. Pengikutsertaan guru dalam pendidikan lanjut ini dapat dilaksanakan dengan memberikan tugas belajar baik dalam maupun luar negeri bagi guru yang berprestasi. Pelaksanaan pendidikan lanjut ini akan menghasilkan guru-guru pembina yang dapat membantu guru-guru lain dalam upaya pengembangan profesi.

\section{Non-pendidikan dan pelatihan}

a. Diskusi masalah pendidikan. Diskusi ini diselenggarakan secara berkala dengan topik diskusi sesuai dengan masalah yang dialami di sekolah.

b. Seminar, kengikutsertaan guru dalam kegiatan seminar dan pembinaan publikasi ilmiah juga dapat menjadi model pembinaan berkelanjutanbagi peningkatan keprofesian guru. Kegiatan ini memberikan peluang kepada guru untuk berinteraksi secara ilmiah dengan kolega seprofesinya berkaitan dengan hal-hal terkini dalam hal upaya peningkatan kualitas pendidikan.

c. Workshop, kegiatan ini dilakukan untuk menghasilkan produk yang bermanfaat bagi pembelajaran, peningkatan kompetensi maupun pengembangan karirnya. Workshop dapat dilakukan misalnya dalam kegiatan menyusun KTSP, analisis kurikulum, pengembangan silabus, penulisan rencana pembelajaran.

d. Penelitian. Penelitian dapat dilakukan guru dalam bentuk penelitian tindakan kelas, penelitian eksperimen, ataupun jenis lain dalam rangka peningkatan mutu pembelajaran

e. Penulisan buku/bahan ajar. Bahan ajar yang ditulis oleh guru dapat berbentuk diktat, buku pelajaran, ataupun buku dalam bidang pendidikan.

f. Pembuatan media pembelajaran. Media pembelajaran yang dibuat oleh guru dapat berbentuk alat peraga, alat praktikum sederhana, maupun bahan ajar elektronik atau pembelajaran.

g. Pembuatan karya teknologi/karya seni. Karya teknologi/seni yang dibuat guru dapat berupa karya yang bermanfaat untuk masyarakat atau kegiatan pendidikan serta karya seni yang memiliki nilai estetika yang diakui oleh masyarakat.

Selain itu hal-hal penting yang perlu diperhatikan dalam pengembangan profesionalisme guru Agama Hindu adalah adanya perhatian dari pemerintah secara berkelanjutan pada setiap satuan dan jenjang pendidikan yang ada, demikian pula guru agama Hindu hendaknya mampu mengembangkan profesionalisme secara optimal sesuai tuntutan masyarakat terutama dalam menghadapi era globalisasi.

\subsection{Profesionalisme Guru Agama Hindu}

Dalam upaya untuk mampu menjadi guru agama Hindu yang profesional, maka sangat diperlukan sekali dalam memahami ajaran agama Hindu secara utuh dan tidak sepotongsepotong dan dalam penyampaiannya harus disesuaikan dengan perkembangan jaman. Salah satu cara memahami agama Hindu secara menyeluruh dapat dilakukan melalui pendekatan sejarah, kepustakaan, struktur ajaran, budaya pendukung dan dinamika kehidupan dengan media IPTEKS sebagai media pendukungnya. 
Pemahaman ajaran agama Hindu harus senantiasa terus di-update dalam konteks kekinian sehingga dalam penyampaiannya seirama dengan perkembangan jaman. Sebagian besar materi ajar yang berskala internasional bisa di-upload dan di-download dari interconnected network (internet). Dengan demikian, kemajuan IPTEKS semestinya dimanfaatkan secara maksimal untuk kepentingan pembelajaran.

Dari pendekatan sejarah dapat diketahui bahwa agama Hindu adalah agama terbuka, agama berkelanjutan sehingga melahirkan bentuk-bentuk baru walaupun azasnya tetap sama. Demikianlah misalnya paham Weda melanjut ke paham Upanisad yang memandang Yang Maha Kuasa adalah Brahman yang melahirkan ajaran Wedanta. Ajaran Wedanta melanjut ke dalam ajaran Purana yang mengajarkan paham Brahma, Wisnu dan Siwa. Ajaran Tantra yang memuja Sakti menyertai paham Brahma, Wisnu dan Siwa.

Dari pendekatan kepustakaan menunjukkan bahwa setelah Weda kepustakaan Hindu berlanjut terus. Dari Weda muncul buku-buku Brahmana dan melanjut menjadi Aranyaka, Upanisad, Dharmasastra, Itihasa, Purana, Darsana, Tantra dan kemudian disarikan di Jawa dalam bentukbentuk lontar. Lontar-lontar inilah menjadi dasar pelaksanaan agama Hindu di Bali.

Dari pendekatan struktur ajaran dapat dilihat dalam Weda bila Agni dewa tertinggi, maka semua dewa adalah Agni, dalam Upanisad semua yang ada adalah Brahman. Agama Hindu di Bali yang memuja Sang Hyang Widhi sebagai Bhatara Siwa, memandang bahwa Bhatara Siwalah semua bhatara-bhatara, bhutakala itu. Hal ini digambarkan Bhatara Siwa yang Esa menjadi delapan dewata dalam pangider-ider.

Walaupun tidak ada sumber sastra menyebutkan, dalam kenyataannya ajaran agama Hindu Bali dapat dipilah menjadi tattwa, tatasusila dan upakara. Ketiga bagian ini merupakan satu kesatuan yang tidak dapat dipisah-pisahkan. Seseorang yang pandai dalam tattwa, namun tidak bersusila belum dapat dikatakan pemeluk agama Hindu yang baik. Seseorang yang tingkah lakunya baik namun tidak pernah sembahyang, tidak pernah mempersembahkan upakara juga belum dapat dikatakan sebagai seorang pemeluk agama Hindu yang baik. Demikian seterusnya. Ketiga bagian ajaran itu saling melengkapi satu dengan yang lain dan dilaksanakan dalam perimbangan yang berbeda.

Umat Hindu di Bali lebih menonjol dalam pelaksanaan yajna dalam wujud mempersembahkan upakara dari yang lainnya. Hal ini dapat disebabkan karena melaksanakan yajna mudah ditangkap indriya yang membawa perasaan seseorang ke alam religius. Di samping itu dapat dilaksanakan bersamasama di masyarakat dalam kegembiraan dan kesemarakan. Berbagai-bagai hasil budaya dapat diaplikasikan untuk menunjang pelaksanaan yajna itu. Ibadah agama dalam wujud yajna, dalam wujud ritual merupakan penguat, pengikat, perekat, dan perawat iman umat Hindu di Bali. Sampai sekarang pelaksanaan hidup beragama Hindu di Bali ternyata tertata rapi dalam kebersamaan yang serasi dalam wujud persembahan bhakti dengan sarana upakara. Semua pelaksanaan yajna itu merupakan realisasi ajaran tattwa. Semua ini merupakan pelaksanaan hidup beragama melalui prawretti marga. Niwretti marga dilaksanakan oleh orang-orang tertentu sifatnya individu.

\section{SIMPULAN}

Untuk dapat menjadi guru agama Hindu yang profesional, maka sangat diperlukan usaha yang maksimal untuk menggali potensi yang ada pada setiap pribadi para guru. Untuk mecapai hasil yang maksimal, maka disiplin dan kesadaran diri sangat perlu ditumbuhkembangan. Dalam pembelajaran agama sebaiknya berkelanjutan, yaitu mulai dari 
mengetahui, mengerti, memahami dan menghayati serta mampu menjadikan agama itu dirinya. Akan tetapi, dalam realisasi ajarannya akan selalu diupayakan kontekstual yaitu disesuaikan dengan ruang dan waktu, serta dalam proses pengajaran agama Hindu hendaknya mengikuti perkembangan zaman dengan mengoptimalkan penggunaan teknologi dan informasi. Dengan demikian, kita sebagai generasi pelanjut dan penerus dari warisan nenek moyang agar senatiasa mampu berenang dalam perubahan dengan pendekatan yang humanis agar harmoni dapat terwujud dalam segala aspek kehidupan, yang sudah tentunya harus seirama dengan perkembangan jaman dengan memanfaatkan kemajuan ilmu pengetahuan dan teknologi informasi secara maksimal yang disesuaikan dengan ruang dan waktu.

\section{DAPTAR PUSTAKA}

Alma, Buchari. 2010. Guru Profesional Menguasai Metode dan Terampil Mengajar. Bandung: Alfabeta

Barnawi, \& Arifin, Mohammad. 2012.a. Etika dan Profesi Kependidikan. Jogjakarta: Ar-Ruzz Media

Barnawi, \& Arifin, Mohammad. 2012.b. Kinerja Guru Profesional. Jogjakarta: Ar-Ruzz Media

Bafadal, Ibrahim. 2004. Peningkatan Profesionalisme Guru Sekolah Dasar. Jakarta: PT Bumi Aksara.

Danim, Sudarwan. 2011. Pengembangan Profesi Guru dari Pra-jabatan ke Profesional. Jakarta: Kencana Praneda Media Group.
Danim, Sudarwan. 2010. Pedagogi, Andragogi, dan Heutagogi. Bandung: Alfabeta.

Hamalik, 2006. Pendidikan Guru Berdasarkan Pendekatan Kompetensi. Bandung: Bumi Aksara.

Rizali, A., Sidi, D, I \& Dharma, S. 2009. Dari Guru Konvesional Menuju Guru Profesional. Jakarta: PT. Gramedia.

Rusman. 2011. Model-model Pembelajaran Mengembangkan Profesionalisme Guru. Jakarta. Rajawali Press.

Sura, I Gede. 1990. Azas Ketuhanan dan Etika Dalam Ajaran Agama Hindu. Stensilan.

Sura, I Gede, Ida Bagus Kade Sindhu, I Gusti Ketut Dalem. 1994. Agama Hindu Sebuah Pengantar. Denpasar : Kayu Mas Agung

Surya, Mohamad, 2004. Psikologi Pembelajaran dan Pengajaran. Bandung: Pustaka Bani Quraisy.

Sutisna, Oteng. 1983. Administrasi Pendidikan Dasar Teoritis untuk Praktek Profesional. Bandung: Angkasa.

Tim Penyusun. 1996/1997. Pedoman Sembahyang, Denpasar. Pemerintah Daerah Tingak I Bali.

Usman, U, M. 2011. Menjadi Guru Profesional. Bandung: PT. Remaja Rosdakarya.

Undang-undang RI Nomor. 14 Tahun 2005 tentang Guru dan Dosen. 